\title{
Ashtanga Yoga for Individual and Societal Wellbeing
}

\author{
M Y Manjula*
}

\section{Abstract}

Are happiness and well-being are not synonymous? Some say yes. There are others who say well-being = happiness + meaning. Subjective wellbeing (SWB) is the aspect of happiness that can be empirically measured. It is a combination of positive affect and general life satisfaction. This study explores Ashtanga Yoga as a tool for individual and societal wellbeing. Yoga is not a set of contorted postures and breathing exercises as it is being popularised today. The yogic way of life is not otherworldly. It offers a holistic life style full of bliss, peace and tranquillity. A person who is tranquil and has peace within himself will spread it around, and in the process peace, tranquillity, happiness and wellbeing will prevail in such a society.

Keywords: Asthanga yoga, Well - being

\section{Introduction:}

Wellbeing is defined in the dictionaries as a good or satisfactory condition of existence; a condition characterized by health, happiness and prosperity. Psychologists who support the hedonic perspective view subjective well-being and happiness as synonymous. Alternatively, the scholars whose ideas about wellbeing are more consistent with Aristotle's views on euduaimonia

\footnotetext{
* Reader and Head, Department of Postgraduate Studies and Research in Psychology, SDM College, Ujire - 574 240, Karnataka, India; mymanjula@gmail.com
} 
believe that happiness and well-being are not synonymous. In this latter perspective, eudaimonia is comprised of happiness and meaning. Stated in a simple formula, well-being= happiness+meaning (Snyder and Lopez, 2007). Ed Diener (1984) coined the term subjective wellbeing (SWB) as the aspect of happiness that can be empirically measured. According to Diener subjective wellbeing is a combination of positive affect (in the absence of negative affect) and general life satisfaction (i.e. subjective appreciations of life's rewards).

\section{Indices of wellbeing:}

Internationally several indices like GDP, HDI, PQLI, Happy Planet Index and GNH have been used to assess wellbeing. GDP (Gross Domestic Product) is more an economic indicator of wellbeing; HDI (Human Development Index) takes into account life expectancy, education and standard of living; PQLI (Physical Quality of Life Index) includes basic literacy, infant mortality and life expectancy as the indices; the happy planet index is unique in that along with the standard determinants, it also includes the country's ecological footprint as an indicator of wellbeing. But a more holistic and unique measure of wellbeing is the GNH (Gross National Happiness) developed by Bhutan, which takes into account the level of happiness as the indicator of wellbeing.

The pursuit of happiness has been the topic of discussion in religious writings, philosophical texts, and proclamations of the American forefathers (Snyder \& Lopez, 2007). All individual religions work towards building a united peaceful society and increasing the wellbeing of the members of the society. Religious approach appeals to the believers of that religion but it has its own limitations. It is likely to drive non-believers away. Religious approach has to be supplemented or complemented by secular non-religious approaches. Yoga is a secular and comprehensive approach which gives emphasis to individual and social wellbeing. Since yoga originated in India there is a tendency on the part of the people to associate it with Hinduism. But associating yoga with any religion is having a very limited understanding of yoga.

There is a good deal of interest in yoga currently the world over for a variety of reasons. 
- Some have taken recourse to yoga for its therapeutic effects.

- Some feel attracted to it because of the miraculous powers which its practice is supposed to confer.

- Some do it as a good physical exercise

- Some have sought after it as an antidote against a life of boredom resulting from a surfeit of comforts and selfindulgence.

- There is however very little understanding that yoga is something more than a physical or mental drill, that it is a method for the development of the physical, social, cognitive, moral and spiritual potentialities of man (Yardi, 1979).

Yoga is not a set of contorted postures and breathing exercises as it is being popularised today. It is actually a way of life. Yoga is quite possibly the most ancient science known to man. Seals depicting human figures in various yoga postures have been unearthed in the Indus valley, where the findings date back to more than 5,000 years (Walters, 2003).

Yoga is one of the six schools of Indian philosophy. The six schools are Sankhya, Vedanta, Vaisheshika, Nyaya, Mimamsa and Yoga. Sankhya offers a framework for all the levels of manifestation from the subtlest to the grossest. Vedanta mentions about the contemplative methods of self-inquiry. Vaisheshika includes exploring the elements of earth, water, fire, air and space, as well as time, mind and soul. Nyaya deals with logic which is the process of reasoning. Mimamsa deals with philosophy related to ritual, worship and ethical conduct. Yoga systematically deals with all of the levels of one are being, striving to experience the eternal centre of consciousness. Yoga is often called Sankhya-Yoga, as it contains the practical methods to realize in direct experience the truths of Sankhya philosophy.

Though different researchers talk about different types of yoga. The more commonly discussed types of yoga are four. They are the Bhakti yoga, Karma yoga, Jnana yoga and Raja yoga. Devotion is the path adopted by a person who opts for Bhakti yoga. Karma yoga, the active man finds realization through the path of work; this person dedicates the fruits of his 
action to humanity. Jnana yoga, the intellectual man pursues it through acquiring and spreading knowledge. Raja yoga, the royal path, this highly scientific path was systematized by Patanjali, the codifier of yoga,. By following it one learns to control his desires, emotions and thoughts (Rama, 1998). A person adopting this path realizes his divinity through the control of the mind.

Asana-based yoga is rooted in the hatha yoga tradition in which asana (postures), pranayama (breathing exercises) and meditation form a tripod of spiritual practices aimed at developing one's internal energies. Hathayoga lays considerable stress on the six purificatory actions (satkarmas) as preparatory stages and a number of exercises known as mudras as their crowning achievements. Hathayoga is thus essentially a physical discipline, which is usually undertaken to obtain worldly benefits such as health, cure of disease and longevity. (Frawley \& Kozak 2003)

Ashtangayoga concentrates on engineering the self and society by its secular practices. Yogic way of life propagates that individual and societal wellbeing are interdependent and one cannot exist without the other. Patanjali has long been known as the celebrated author of the yogasutras (Yardi, 1979). Ashtanga yoga, as the name itself indicates, has ashta (eight) steps. They are yama, niyama, asana, pranayama, prathyahara, dharana, dhyana and Samadhi.

The rungs of asana and pranayama are preceded by yama and niyama as these are the moral codes or ten commitments of raja yoga. The value of asana and pranayama are limited if they are not taught in conjunction with yamas and niyamas. (Rama, 1998)

\section{Yamas}

Yamas are the ethical principles. The yamas are practices to eliminate wrong, harmful or disturbing behaviour. They create a foundation of right living, peace and harmony both at the individual and social level. The yamas provide a simple model of self-discipline that eliminates the problems that arise through materialistic ways of living. (Frawley \& Kozak, 2003). The yamas are:

1. Ahimsa (non-violence): Ahimsa is a term that was popularized in our times by Mahatma Gandhi. By non-violent resistance he led 
India to political emancipation from Britain. (Walters, 2004). Violence arises out of fear, weakness, ignorance or restlessness. Violence is bound to decline when men learn to base their faith upon reality and investigation rather than upon ignorance and supposition. Along with ahimsa goes abhaya i.e. freedom from fear and akrodha i.e. freedom from anger. Freedom from fear comes only to those who lead a pure life (Iyengar, 2007). Harming others whether through thought, action or emotion-always harms us as well. Non-harming implies avoiding any actions that cause harm and promoting those that reduce harm or protect from injury. Nonviolence not only means not killing but also applies to non-violence in thoughts, feelings and deeds. On the positive side careful cultivation of ahimsa leads to a spontaneous, all-encompassing love (Rama, 1998). As the saying goes when we are good to others we are best to ourselves, because when we nurture positive emotions we have more of the endorphins released and that makes us feel good.

2. Satya: Satya or truth is the highest rule of conduct or morality. Mahatma Gandhi said truth is god and god is truth. Reality in its fundamental nature is love and truth and expresses itself through these two aspects. Truth is not limited to speech alone. There are four sins of speech-abuse and obscenity dealing in falsehoods, calumny or telling tales, and lastly ridiculing what others hold to be sacred. The control of speech leads to the rooting out of malice. Truthfulness in thought and conduct is necessary for clarity and peace of mind and for creating social interactions that establish trust and eliminate conflict. Truthfulness begins with ourselves (Iyengar, 2007).

3. Asteya: The desire to possess and enjoy what another has, drives a person to do evil deeds. From this desire springs the urge to steal and the urge to covet. Stealing includes not only taking what belongs to another without permission but also using something for a different purpose other than the one that it is intended for. It thus includes misappropriation, breach of trust, mismanagement and misuse.

4. Brahmacharya: According to dictionary Brahmacharya means the life of celibacy, religious study and self-restraint. Brahmacharya 
means avoiding sexual misconduct, which is a great cause of both deception and harm to self and others. Wrong use of sexual energy is the main factor of social and psychological suffering (Frawley \& Kozak, 2003). Brahmacharya should not be interpreted as repression of sensual urges-repression leads to frustration. Brahmacharya means control of and freedom from all sensual cravings. (Rama, 1998).

5. Aparigraha: Parigraha means hoarding or collecting. To be free from hoarding is aparigraha. It is thus but another facet of asteya. One should not hoard or collect things one does not require immediately. By the observance of aparigraha, a person can make his life as simple as possible. Aaparigraha does not mean depriving oneself of all material possessions. It means not being addicted to, or dependent on one's possessions rather than the outward denial of them (Rama, 1998). We know that nothing in nature is infinite. If some people hoard they will be depriving the others. According to world institute of development economics research the richest two percent of adults in the world own more than half of household wealth; richest $10 \%$ account for $85 \%$ of the world's total wealth, and the bottom half owns barely one percent of global wealth (Hanlon, 2006) and this creates imbalance in the distribution of wealth and leads to an inequitable society. History has shown us that inequitable societies become the harbingers of violence.

Along with abstinences, which are restraints, yoga recommends the practice of observances or niyamas.

\section{Niyama:}

These are the rules of conduct that apply to individual discipline while yamas are universal in their application. These are principles of personal practice both for self-healing and self-development. Who we are is the result of how we live and act on a daily basis (Frawley \& Kozak, 2003).

1. Swacha: Purity; purity of body is essential for well-being. While habits like bathing purify the body externally, asana and pranayama cleanse it internally. The practice of asanas tones the entire body and removes the toxins and impurities caused by overindulgence. It also implies cleansing the mind of impure thoughts. 
Purity and cleanliness also refer to purity of heart and mind. We must be free of mental and physical toxins in order to function with full vitality and capacity. A clean mind, free of neediness, avarice, fear, and other emotional impediments creates clarity and wisdom. (Frawley \& Kozak, 2003).

2. Santosha: Santosa or contentment has to be cultivated. Contentment is being happy with what one is and what one has. Contentment and tranquillity are states of mind.

3. Tapas: means discipline, referring to a steady application of the will to achieve a meaningful goal, which implies being able to sacrifice lesser pursuits along the way. To continue to work toward and achieve a higher consciousness we must remain steady in our exercise of tapas (Frawley \& Kozak, 2003).

4. Svadhyaya: Sva means self and adhyaya means study or education. Svadhayaya is study leading to the knowledge of the self. This begins with intellectual pursuits (Rama, 1998).

5. Isvarapranidhana: Surrender to the divine or cosmic will is not a matter of mere religious belief. It means to sublimate the ego and its needs to the higher consciousness working through life and governing this vast universe. With the ego integrated it is possible to experience the whole rather than remain trapped in the small I. (Frawley \& Kozak, 2003).

\section{Asana:}

The third limb of yoga is asana or posture. Asana brings steadiness, health and lightness of limb. A steady and pleasant posture produces mental equilibrium and prevents fickleness of mind. Asanas are not merely gymnastic exercises; they are postures. Asanas are practiced slowly and steadily which bring about physical and mental relaxation. By practicing them one develops agility, balance, endurance and great vitality. Asanas have evolved over the centuries so as to exercise every muscle, nerve and gland in the body. Regular practice of asana helps in securing a fine physique which is strong and elastic without being muscle-bound and they keep the body free from disease. They reduce fatigue and soothe the nerves. But the real importance lies in the way they train 
and discipline the mind. The names of the asanas are significant and illustrate the principle of evolution. Asanas are named after vegetation, insects, birds and animals (Gore, 2005).

Asanas are psycho-physical practices to culture body and mind for further higher practices of yoga. The main objective of asanas is to promote and maintain perfect health. They re-establish the harmonious functioning of the body and mind as one integrated whole.

\section{Classification of asanas:}

Considering the anatomico-physiological features, asanas can be classified into three major groups:

A. Cultural asanas: This group includes maximum number of asanas, which are meant for re-conditioning of the body and mind so as to bring about stability, peace and a sense of well-being.

Asanas working on the spinal column: Although the action of almost all the cultural asanas is on the spinal column, this group of asanas work mainly on the joints, ligaments, muscles and the associated nerves of the vertebral column. E.g. Bhujangasana, chakrasana, vakrasana, ushtrasana etc.

Asanas working on interoceptors (a sensory receptor of an internal organ excluding the muscles):

a. Asanas working on and through proprioceptors: (special nerve endings in the muscles and tendons and other organs that respond to stimuli regarding the position and movement of the body). These asanas predominantly work on and through various proprioceptors mechanisms of the skeletal muscles of the body. Stimulation of the proprioceptors gives rise to stretch reflexes.

E.g. baddhapadmasana, gomukhasana, matsyasana, vajrasana, trikonasana, bhadrasana, padahastasana, sputa-vajrasana.

b. asanas working on and through visceroceptors: Visceral organs are subjected to the pressure changes brought about in the intraabdominal cavity. The visceroceptors in the walls of these organs, on stimulation, send sensory impulses to autonomic nervous centers. E.g. yogamudra, paschimottanasana, mayurasana, 
ardhamatsyendrasana, supta-vajrasana, halasana, pavanmuktasana etc.

\section{Asanas working on vestibular organs:}

These asanas predominantly work on and through the sense organs of balance including vestibular organs. These organs usually maintain the body balance.

The asanas under this group are shirshasana, sarvangasana, viparitkarnigaurdasana, vrishchikasana, vrikshasana, kukkutasana, bakasana, padahastasana. They also influence blood pressure mechanism and the circulation.

B. Meditative asanas: These provide a comfortable and stable position of the body to make the mind more and more steady for the process of meditation, dharana and samadhi. The meditative asanas are padmasana, siddhasana, swastikasana, samasana. The aim of these asanas is to provide a firm and comfortable posture for the practice of pranayama, dhyana, etc., for hours without any physical or mental disturbance. Meditative asanas provide broad triangular base for the body, formed by two femurs and the pelvis. This broad base gives firm foundation to the body and makes it steady and stable. Experimentally it has been observed that the energy requirement in meditative asanas is less than in normal chair-sitting position. This is mainly because of the low oxygen requirement of the body and reduced production of carbon dioxide on account of negligible muscular activity in the body and reduced burden on the circulatory function. As a result the cardiorespiratory activity is also greatly reduced.

C. Relaxative asanas: Shavasana and makarasana are two important relaxative asanas. They bring about relaxation of the body and mind. They eliminate the physical as well as mental tensions and work at the level of chitta (subtle aspect of consciousness). Shavasana makes the individual fresh and energetic. It helps overcome physical as well as the mental fatigue or exertion. Relaxation in shavasana renders the mind more calm and tranquil (Gore, 2005). 


\section{Pranayama:}

Prana means breath and ayama means length, expansion, stretching or restraint. Pranayama thus connotes extension of breath and its control. It is a conscious prolongation of inhalation, exhalation and retention. Pranayama is the science of breath. It is the hub around which the wheel of life revolves. A serious student of yoga is expected to start practice of pranayama when he becomes well versed in asanas. Pranayama is a process by which the mind is controlled by voluntary regulation of the breathing (Gorey, 2005). The science of pranayama is intimately connected with the functions of the autonomic nervous system and its techniques are aimed at bringing those functions (normally considered involuntary) under voluntary control. Pranayama is a complex and highly developed science. There are a few fundamental exercises like nadishodhana which is done to cleanse the two nadis or energy channels; kapalabhati to clean the sinuses, respiratory passages and to stimulate the digestive organs and abdominal muscles and several other advanced pranayama techniques which have promotive and curative value (Rama, 1998).

The above four steps are considered as steps of bahirangasadhana or outer quest. The next four steps are for antharangasadhana or inner quest.

\section{Prathyahara:}

The fifth step of raja yoga is pratyahara or withdrawal and control of the senses. The practice of prathyahara requires the individual to voluntarily draw the senses inward and thus isolate himself from the distractions of the world outside. Most pratyahara methods consist of withdrawing from external sensory overload and accessing the peace and silence within ourselves. Deep relaxation is also part of pratyahara, which involves putting the motor organs to rest (Frawley \& Kozak, 2003).

\section{Dharana:}

Dharana is the sixth step in raja yoga. In concentration the dissipated powers of the mind are gathered together and directed 
toward the object of concentration through continued voluntary attention. In concentration all mental energies are brought to bear on one object or idea (Rama, 1998). Dharana consists of concentration practices that focus and stabilize our attention. Attention is the main power of the mind. Attention is pre-requisite for acquiring higher mental capacities. By cultivating the power of attention all the powers of the mind are gradually opened up to us (Frawley \& Kozak, 2003). Dharana is the concentration of the mind and Swami Vivekananda rightly said that concentration is the best power we have. Mind is the product of thoughts which are difficult to restrain for they are subtle and fickle. The mind is the instrument for thinking and there we need to understand how it functions. Mental states are classified into five groups: Ksipta state: Here the mental forces are scattered, being in disarray and in a state of neglect; Viksipta state: here the mind is agitated and distracted; Mudha state: Here the mind is foolish, dull and stupid. It is confounded and at a loss to know what it wants and here the tamoguna predominates; Ekagra state: The mind is closely attentive and the mental faculties are concentrated on a single object or focused on one point only. Niruddha: The mind, intellect and ego are all restrained (Iyengar, 2007). There are definite techniques to improve the concentration. Trataka is one of the techniques for improving concentration. Hatha yoga mentions that by performing trataka regularly, eye disorders are cured and lethargy is overcome (Gorey, 2005).

Physiology of trataka: It has been found that soon after trataka is over, the parasympathetic predominance is established as indicated by lowering of heart rate and respiration rate as well as an increase in amplitude of plethysmogram (vasodilation). That means peripheral blood circulation is increased after trataka. Emotional balance or stability is restored and the degree of relaxation is increased as indicated by the production of well-modulated train of alpha frequency after trataka. One-pointed concentration is improved, and attention fluctuations are reduced. (Gorey, 2005 ) 


\section{Dhyana:}

Sankhya school of philosophy defines dhyana as the liberation of the mind from all disturbing and distracting emotions, thoughts and desires (Rama, 1998). Dhyana refers to meditation which is a sustained concentration or deep reflection of a particular object of thought. Through holding a one-pointed attention, we can arrive at a deep understanding of the reality of whatever we meditate on. Whatever we fully give our attention to in a consistent manner unfolds its inner meaning for us. All of life speaks to us if we can enter the meditative mind. The greatest instrument of knowledge is not any machine or any book but our own awareness once it is steady (Frawley \& Kozak, 2003). Mindfulness meditation is also known to reduce the discrepancy between real and ideal self (Ivtzan, Gardner \& Smailova, 2011)

\section{Samadhi:}

In Patanjali's school of raja yoga, it is mentioned that prolonged concentration leads to meditation, and meditation expands the mind into the superconscious state called Samadhi (Rama, 1998).

\section{Conclusion:}

The task of modern science is to produce a good society as well as a good person, because the actualization of human potentialities on a mass basis is possible only under favourable social conditions (Maslow, 1969). Raja yoga (ashtanga yoga) leads the practitioner to the final state of realization, not by training the intellect alone, but by training the whole person, thus making him more useful to himself and to humanity (Rama, 1998).

In its practical aspect yoga affirms that the simultaneous development of the intellect and the moral sense is essential for the harmonious and integrated development of personality and that this could be achieved only through the restraint of the cognitive affective states of the mind. Universal acceptance of Patanjali's ethical approach to life's problems would lead to the solution of the world's most pressing problems. Yoga, in common with Jainism and Buddhism, lays great emphasis on renunciation of violence 
and of the acquisitive spirit parigraha. According to Patanjali, deeds should be deemed to be virtuous or wicked according to whether they involve doing good or harm to others. Hence the moral basis of any action, whether of an individual or the state, has to be judged by the extent to which it contributes to human happiness or suffering (Yardi, 1979).

The yogic way of life is not other-worldly. It offers a holistic life style full of bliss, peace and tranquillity. A person who is tranquil and has peace within himself will also spread it around and in the process peace, tranquillity, happiness and wellbeing will prevail in such a society.

\section{References:}

Diener, E., (1984). Subjective well-being: Psychological Bulletin 95, 542-575

Frawley, D, Kozak, S. S. (2003) 1'stIndian edition; 2006 reprint Yoga for your type: An ayurvedic approach to asana practice, New Delhi, New Age Books.

Gore, M. M. (2005). Anatomy and physiology of yogic practices. New Delhi, NewAge Books.

Hanlon, M. (2006). How the worlds wealth is distributed - the top two percent own half. Retrieved from http://www.gizmag.com/go/6571/

Ivtzan I, Gardner H.E., \& Smailova Z, (2011). Mindfulness meditation and curiosity: The contributing factors to wellbeing and the process of closing the self-discrepancy gap. Retrieved from http://www.internationaljournalofwellbeing.org/index.

Iyengar B. K. S. (2007). Light on yoga. New Delhi, Harper Collins publishers India.

Maslow (1969) as cited in Coleman, J.C. (1972). Abnormal Psychology and Modern Life, $4^{\text {th }}$ ed., Chicago, Scott Foressman.

Rama, S. (1998). The royal path practical lessons on yoga. Pennsylvania, The Himalayan Institute press.

Snyder C.R. and Lopez S.J. (2007). Positive psychology: The scientific and practical exploratios of human strengths. Thousand Oaks, CA: SAGE Publications.

Swaminathan V.D.,Kaliappan K.V. (1997). Psychology for effective living, behaviour modification, guidance, counselling and yoga. Chennai, Madras Psychology Society. 
Walters, J. D. (Swami Kriyananda) (2003), The art and science of Raja Yoga: Fourteen steps to higher awareness. Delhi, Motilal Banarasidas.

Yardi, M.R. (1979). The Yoga of Patanjali, Pune, Bhandarkar Oriental Research Institute. 